\title{
Extracellular DNA as an essential component and therapeutic target of microbial biofilm
}

\section{Zewnątrzkomórkowy DNA jako istotny składnik oraz cel terapeutyczny biofilmu bakteryjnego}

\author{
Urszula Wnorowska, Marzena Wątek², Bonita Durnaś3 ${ }^{3}$ Katarzyna Głuszek¹, Ewelina Piktel', \\ Katarzyna Niemirowicz ${ }^{1}$, Robert Bucki ${ }^{1,4}$ \\ 1Department of Microbiological and Nanobiomedical Engineering, Medical University of Bialystok, Bialystok, Poland \\ Head of the Department: Prof. Robert Bucki PhD \\ 2Department of Haematology, Holy Cross Oncology Centre of Kielce, Kielce, Poland \\ Head of the Department: Marcin Pasiarski MD, PhD \\ ${ }^{3}$ Department of Clinical Microbiology, Holy Cross Oncology Centre of Kielce, Kielce, Poland \\ Head of the Department: Bonita Durnaś MD, PhD \\ ${ }^{4}$ Department of Pathophysiology and Infection Microbiology, Institute of Nursing and Obstetrics, Faculty of Health Sciences, \\ Jan Kochanowski University, Kielce, Poland \\ Head of the Department: Prof. Robert Bucki MD, PhD
}

Key words: extracellular DNA (eDNA), biofilm, DNase I.

Słowa kluczowe: zewnątrzkomórkowy DNA, biofilm, DNaza I.

\begin{abstract}
The dominant part of human infections is associated with biofilm formations. Biofilm represents structured communities of bacterial or fungal cells enclosed in self-produced polymeric matrixes adherent to supporting surfaces. Microbial DNA and the host cell DNA, after their release at the infection site, show the ability to promote biofilm formation. Between the different constituents of biofilm matrixes, extracellular DNA (eDNA) may be the only component indispensable for the initial attachment and early biofilm formation through an enhanced matrix structural integrity. The effect of DNA on bacterial/fungal attachment is non-specific, as indicated by the stimulatory effect of plasmid, chromosome, or eukaryotic DNA. DNase I impaired bacterial biofilm growth and the targeting eDNA were recently proposed to eliminate and/or prevent different microbial infections associated with biofilm formations.
\end{abstract}

\section{Streszczenie}

Znaczna część infekcji występujących u ludzi jest związana z powstawaniem biofilmu. Biofilm stanowi złożoną strukturę składającą się z drobnoustrojów oraz wyprodukowanej przez nie polimerowej macierzy, umożliwiającej adhezję do różnych powierzchni. Drobnoustrojowe oraz ludzkie DNA, pochodzące odpowiednio z mikroorganizmów i komórek gospodarza, uwalniane w miejscu infekcji działa jako czynnik promujący rozwój biofilmu. Uważa się, że zewnątrzkomórkowe DNA (eDNA), dzięki zwiększeniu integralności konstrukcji macierzy, jest niezbędnym elementem biorącym udział w adhezji bakterii do podłoża i wczesnym formowaniu się biofilmu. Wyniki badań wykorzystujących plazmidy, chromosomy oraz eukariotyczne DNA wykazały, że wpływ eDNA na rozwój biofilmu jest niespecyficzny i niezwiązany bezpośrednio ze źródłem materiału genetycznego. DNaza I hamuje powstawanie biofilmu. Postuluje się, że wykorzystanie eDNA jako celu terapeutycznego może mieć istotne znaczenie w zapobieganiu i leczeniu zakażeń związanych z formowaniem się biofilmu.

\section{Introduction}

The process of bacterial biofilm development consists of an initial adhesion and the aggregation of dispersal cells from mature biofilm, which are encased in self-produced extracellular polymeric substances (EPSs) [1, 2]. The polysaccharides, host F-actin, and extracellular DNA (eDNA) are the major components present in a biofilm matrix [3]. The majority of these molecules are recognised by the innate immune system via toll-like receptors (TLR), a family of membrane proteins [4,5]. Extracellular polymeric substances can interact with antibiotics, which decreases their antibacterial potential $[6,7]$. eDNA is a crucial component of the biofilm matrix during the first stages of biofilm formation $[8,9]$. In some cases, eDNA might represent 


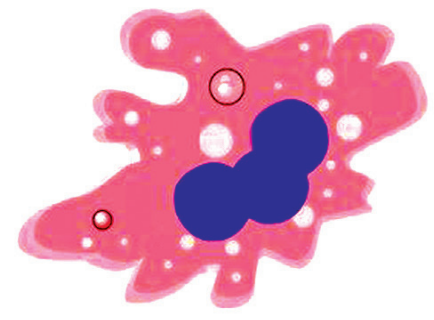

Neutrophil necrosis (release of NETs)
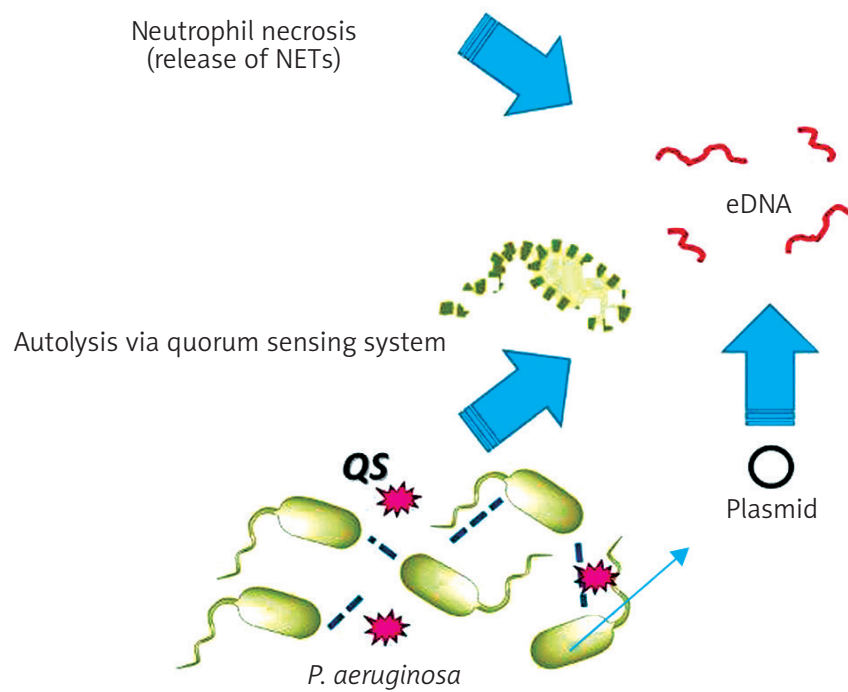

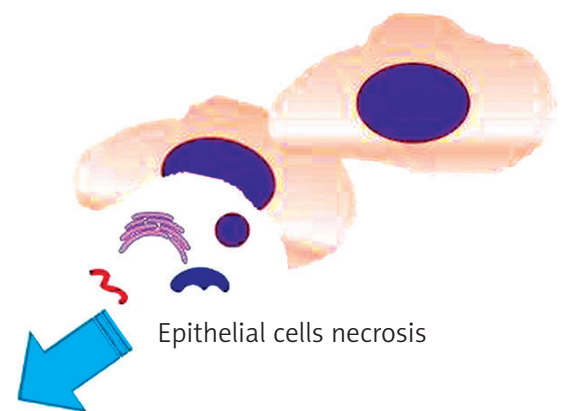

Epithelial cells necrosis

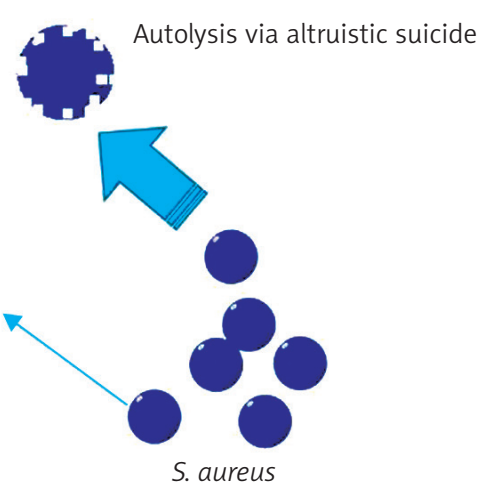

Figure 1. Extracellular DNA (eDNA) accumulation at the infection sites might occur as a result of DNA released from host cells and infecting bacteria cells. DNA from neutrophils might be release in the form of neutrophil extracellular traps (NETs) as part of an antimicrobial response in which neutrophils weave web-like nets. DNA released from other host cells usually follow a necrosis process. Bacteria cells usually release DNA actively based on environmentally dependent autolysis

the only source of carbon and energy for microbial growth [10]. The DNA network within a biofilm is also involved in gene transfers [11] and the development of antimicrobial resistance $[12,13]$. Many microorganisms release DNA during lysis, which occurs as part of the quorum sensing mechanism and initiates the process of biofilm formation [14] (Figure 1). Large amounts of DNA are released from neutrophils during necrosis or as extracellular traps (NETs), resulting in the accumulation of this polymer at the infection sites, such as those observed in cystic fibrosis (CF) airways [15]. eDNA contributes significantly to sputum viscosity, which can be reduced following the addition of recombinant DNase I [16-18]. Interestingly, eDNA, reduces the biofilm's susceptibility to some antiseptic and disinfectant agents [12, 13].

\section{The important role of eDNA in biofilm architecture, the development of resistant strains, and the host immune response}

The accumulation of eDNA in microbial biofilm plays different functions [19]. Whitchurch et al. reported that the formation of a stable biofilm and the attachment of bacterial cells to culture flow-chambers are prevented by the addition of DNase I to the cul- ture medium [20]. Additionally, the ability of DNase I to reduce mature biofilm masses suggests that eDNA is critical for the integrity of these bacterial communities. This role, in particular, of eDNA in the formation of biofilm structures is supported by an increasing number of studies, reporting the inhibitory effects of numerous antibiotics and DNase I on the growth of established biofilms of various bacteria, used separately or together. Treatment of the biofilms with DNase I significantly reduces neutrophil activation markers. DNase I treatment might dissolve an established 72-hour biofilm; however, much older 84-hour biofilm was more resistant to the addition of DNase I, suggesting that the matrix in mature biofilm may contain substances other than eDNA or that mature biofilms may produce proteolytic exoenzymes to locally deactivate the DNase I [4]. Two mechanisms were proposed to describe the potential of DNase I to inhibit microbial biofilm formation. DNase I might shorten the nucleic acids linked to bacteria surfaces that are involved in bacterial adhesions to environmental components where the biofilm forms. The digestion of eDNA mainly in young biofilms, eliminates the major cell-to-cell adhesion and interconnecting aggregates of microbial cells $[4,21]$. Interestingly, it 


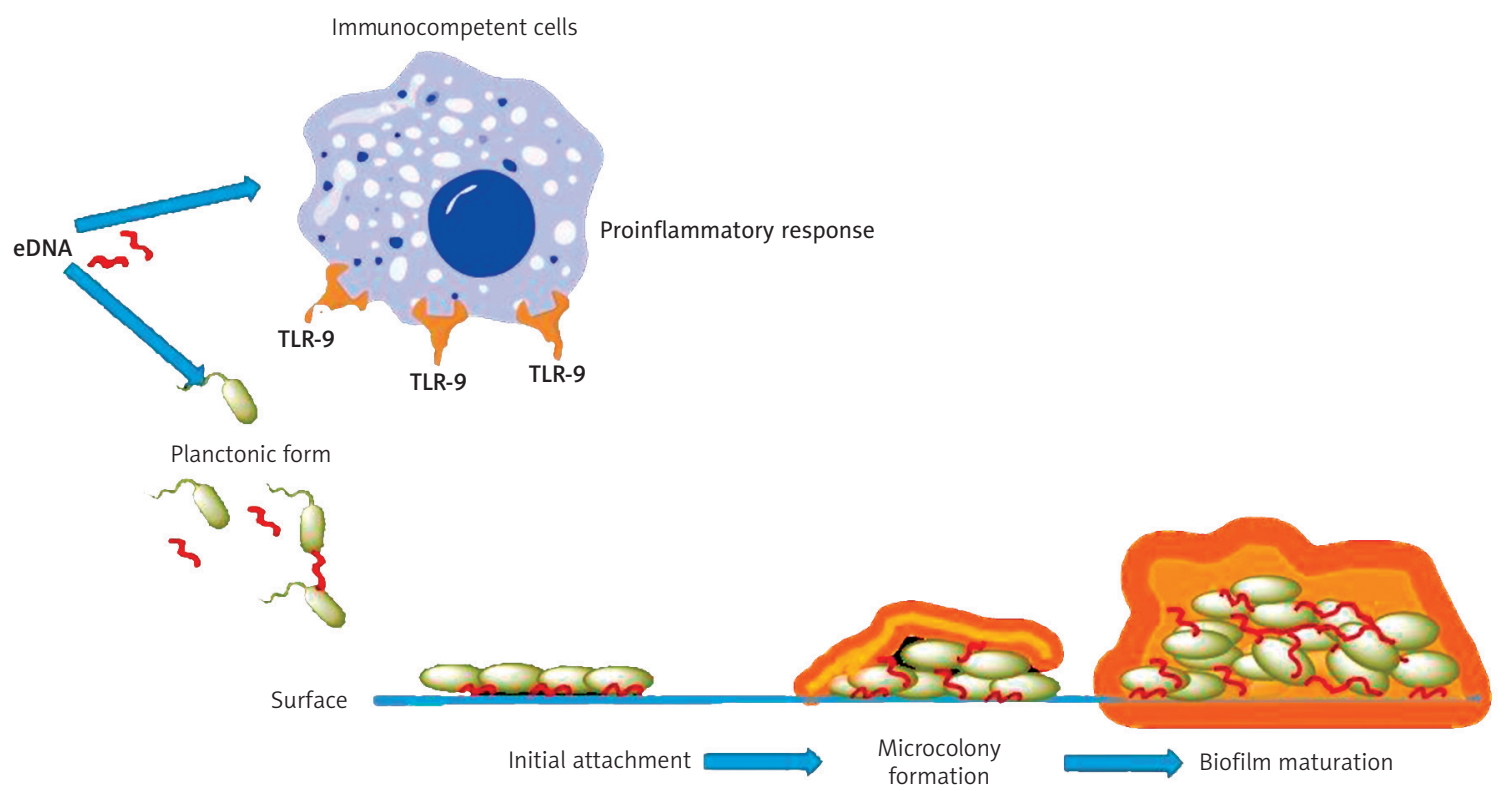

Figure 2. Major functions of extracellular DNA (eDNA) consist of activation or pro-inflammatory responses that involve the activation of TLR9 pathways and the initiation of bacterial biofilm formation

was recently shown that the combination of poly (aspartic acid) with DNase I resulted in a synergistic increase in biofilm disruptions [22]. eDNA is involved in horizontal gene transfers (HTG), which mainly occur through the transformation, conjugation, or transduction of bacterial cells. Transformation requires the availability of eDNA within the environment [23, 24]. eDNA present in bacterial biofilm communities constitutes a dynamic gene pool from which bacteria can derive genetic information by HGT. Acquired antibiotic resistance may be due to a mutation or an acquisition of resistant genes. Biofilm production and eDNA released synergistically, contribute to the development and spread of an antibiotic resistance of HTG [4]. Neutrophils form the first line of defence against invading microbial pathogens - the essential effectors that mediate the phagocytosis and destruction of bacteria through oxygen-dependent and oxygen-independent mechanisms [25]. TLRs recognise pathogen-derived ligands and follow cell activation via the Toll/IL-1R (TIR) signal pathway [26]. TLR9, as an intracellular receptor, is required for a response to the unmethylated CpG motifs of bacterial DNA [27]. TLR2 is critical for the recognition of several pathogens as a Gram-positive bacteria, including bacterial lipoproteins, peptidoglycan (PGN), and lipoteichoic acids [4]. eDNA activates neutrophils through CpGand TLR9-independent mechanisms [25]. eDNA also plays a significant role in neutrophil activation by bacterial biofilms, because the treatment of lasI rhll mutant biofilm with DNase I does not modify its ability to stimulate neutrophil IL-8 and IL-1 $\beta$ [25]. Upon phagocytosis and the digestion of Staphylococcus aureus in the phagosome, bacterial DNA is liberated, and it engages TLR9. TLR9-dependent activation can be triggered not only by phagocytosis of whole $S$. aureus cells, but also by eDNA [19].

\section{Biofilm formation of Pseudomonas aeruginosa strains}

The role of eDNA in bacterial infections has been reported mainly with $P$. aeruginosa infections [12, $28,29]$. During P. aeruginosa infections, eDNA is released mostly by lysis that is regulated by the quorum sensing process [28]. Recent data demonstrates that eDNA from $P$. aeruginosa biofilm matrixes plays a critical role in activating neutrophil proinflammatory responses (Figure 2). Moreover, the data shows that the degradation of eDNA significantly reduces the release of proinflammatory cytokines by neutrophils added to established biofilms, as well as bacterial phagocytosis [25]. Allesen-Holm et al. suggest that extracellular DNA is analogous with chromosomal DNA in $P$. aeruginosa, which serves as a cell-tocell interconnecting component in biofilm matrixes [28]. They also presented out that eDNA is primarily located in high concentrations within the stalks of mushroom-shaped microcolony structures. Montanaro et al. suggest that the presence of eDNA in Pseudomonas biofilms probably has a stabilising role [4]. The stabilisation and structural development of $P$. aeruginosa biofilms depend on the quorum sensing (QS) systems lasRI and rhlRI [30, 31]. In some, the extension of the rhlRI systems is controlled by the lasRI system [31]. Through QS mechanisms, bacteria can monitor their density in cell populations through extracellular signalling molecules [32]. In the case of the 
las system, gene products, lasI, control the synthesis of the actively secreted, extracellular signalling molecule 3-oxo-C12-homoserine lactone (3-oxo-C12-HSL). When the concentration of lactone increases within the environment of cells, following its penetration into a microorganism, the production of the transcriptional activator LasR increases. This complex has the ability to activate the expression of many genes, including enzymes lasA, lasB, and the rhlR-rhlI system [31, 33, 34]. The signal molecules involved are primarily C4-HSLs, in the case of the rhlRI system. The second QS system in $P$. aeruginosa is associated with the regulatory protein RhlR and the C4-AHL (acylated homoserine lactone) molecule, which is the product of the rhlI gene. The C4-AHL molecule connects with the Rhl, which is the transcription activator. This complex (Rhl-C4) regulates the operon responsible for the synthesis of some factors, including rhlAB $[31,35]$. The Pseudomonas quinolone signal (PQS), a third signalling system based on 2-heptyl-3-hydroxy-4-quinolone, is part of the quorum-sensing regulatory network [36]. Allesen-Holm et al. suggest that QS-controlled factors, which might play a regulatory role in biofilm development by $P$. aeruginosa, are associated with programmed DNA releases [28]. Biofilms formed by lasI rhlI mutant strains stimulate lower levels of cytokine production [25]. On the other hand, DNase I treatment inhibits $P$. aeruginosa biofilm growth in vitro $[28,29]$. It was recently shown that the destruction of eDNA could modify the properties of biofilms formed by P. aeruginosa and Streptococcus pneumonia $[20,37,38]$. Is it known that $P$. aeruginosa encodes PEL, PSL, and alginate extracellular polysaccharides. A new report presented that pel-, psl-, and alg-independent biofilms are also regulated by the release of eDNA [39].

\section{Biofilm formation of Staphylococcus aureus strains}

Biofilm formation in S. aureus consists of a two-step process. The initial phase consists of the attachment of cells to a surface, and the second phase consists of cell-cell aggregation and the formation of a multilayered architecture [40]. In S. aureus, the CidA/LrgAB system regulates cell lysis, eDNA releases, and biofilm development by possibly regulating access of murein hydrolases to cell wall substrates [41]. The lrg operon reduces extracellular murein hydrolase activity and increases penicillin tolerance, whereas the cid operon increases extracellular murein hydrolase activity and decreases penicillin tolerance [4]. Furthermore, Rice suggests that eDNA has a biological role in bacterial programmed cell death and cidA mediated lysis. Some results have shown that the treatment of streptococcal biofilm with DNase I inhibits biofilm formation [37, 42]. Houston et al. presented a production of eDNA in $S$. aureus suspension during cell lysis mediated by the autolysin AtlA [43]. The authors also demonstrated the essential role of eDNA in the primary attachment and early stages of Atl-dependent, FnBP-mediated MRSA biofilm. Kaito et al. demonstrated that $S$. aureus colony spreading requires the digestion of eDNA by nucl and nuc2 secretory nucleuses [44]. They believe that two possible mechanisms are involved in blocking the effect of eDNA on $S$. aureus colony spread. The first is associated with increased viscosity of the extracellular matrix that inhibits colony spread. The second is based on the recognition of eDNA by $S$. aureus, resulting in inhibition of the expression of some genes, which leads to the inhibition of colony spread. Kaplan et al. assessed $S$. aureus biofilm formation in the presence of a sub-minimal concentration of $\beta$-lactam antibiotics. They observed that low level concentrations of $\beta$-lactam induce the release of autolysin-dependent eDNA and induce biofilm formation of the $S$. aureus strain [45]. This data remains consistent with other studies demonstrating that eDNA form a major biofilm matrix in $S$. aureus biofilms cultured in a deficiency of antibiotics [38, 41, 43, 46]. The model of the autolysis of $S$. aureus involved an altruistic suicide (Figure 1). Staphylococcus aureus cells may be divided into altruists and survivors, and in the environment that activates biofilm formation, the altruists commit suicide by programmed cell death [4].

\section{Biofilm formation of Staphylococcus epidermidis and Streptococcus pneumoniae strains}

Qin et al. showed that eDNA is a major component, essential for the initial attachment of $S$. epidermidis to surfaces, as well as for the subsequent early phase of biofilm development by this bacteria [47]. Using polymerase chain reaction (PCR), the authors showed that extracellular DNA is similar to genomic DNA. The activity of the autolysin AtlE causes a release of eDNA from S. epidermidis. The eDNA was also found in a wild-type of $S$. epidermidis biofilm. The established biofilms were associated with AtlE-mediated cell lysis [47]. Heilmann et al. investigated another autolysin protein associated with DNA releases in the S. epidermidis. It was named Aae, and it is characterised by bacteriolytic activity and adhesive properties [48]. Interestingly, Vuong et al. reported that the expression of AtlE and the biofilm formation in S. epidermidis were increased in an agr quorum sensing mutant, and it can be linked to DNA releases [47, 49]. Moreover, Izano et al. demonstrated that $S$. epidermidis biofilms were not inhibited and/or detached during DNase I treatment [38]. Streptococcus pneumoniae are characterised by a high prevalence of lysogenic bacteriophages existing in their host chromosome, and the researchers proposed that prophage impulsive activation results in bacterial lysis that provides eDNA. eDNA enhances pneumococcal biofilm development [50]. Streptococcus 
pneumoniae contains a major autolysin LytA, an N-acetyl-muramyl-L-alanine amidase [51]. Moreover, DNA release is associated with cell lysis, dependent upon LytA [52]. The observation that S. pneumoniae biofilm formation depends upon the presence of eDNA and that LytA mutants have a reduced capacity to form biofilms suggests that LytA-induced pneumococcal lysis could be similar with biofilm formations and the release of eDNA $[21,37,50]$.

\section{Fungal biofilms}

The life-threatening infections caused by Candida albicans are often associated with biofilm formation $[53,54]$, and the mainstream displays of candidiasis, at both mucosal and systemic sites, are related to the formation of biofilms [54-56]. The first step of biofilm formation (mainly in Candida glabrata biofilm) is initially conditioned by the activity of adhesion, which is required for surface attachment. Their presence is also necessary for cell-cell stabilisation in the form of a biofilm structure. It was discovered that their expression is strictly correlated with the degree of biofilm development [57]. The stage of fungal biofilm formation is clearly related to the eDNA level. Various studies have shown that eDNA is an important factor in Candida biofilms, including those of C. albicans, C. tropicalis, and C. parapsilosis [58-61]. This is consistent with previous research demonstrating that eDNA is a substantial component of mature $C$. albicans biofilm [58]. Interestingly, studies conducted by Rajendran et al. revealed that the eDNA released during Candida biofilm formation depends upon the fungal species and is connected to biofilm heterogeneity. It was hypothesised that the diversity of biofilms is conditioned upon the difference in the amount of released eDNA - it was assumed that isolates, characterised by their greater ability to form biofilms, liberate more eDNA in comparison with isolates developing structurally simple biofilms. Importantly, eDNA-mediated heterogeneity of fungal biofilm significantly affects the pathogenicity and sensitivity of these pathogens to antifungal agents. Given the above, a detailed investigation of the mechanism of such a phenomenon is required. To date, studies have revealed that the differential degree of biofilm mass formations are associated with chitinase regulated autolytic events [62]. Growth in the pathogenicity of fungi may also be conditioned by morphological transitions of fungi to more invasive forms during biofilm development. Recent studies indicate that eDNA may play a key role in the transition from yeast to hyphal growth in C. albicans cultures. It is worth noting that a low concentration of eDNA is able to induce the transformation of a yeast form [63]. Since hyphal forms are characterised by increasing resistance to antifungal treatment and they play a significant role in C. albicans pathogenicity, the targeting of eDNA is gaining im- portance [64]. It was shown that increases in a biofilm mass is induced by both homogenous and heterogeneous eDNA, which takes on particular significance in light of the studies reporting a major occurrence of polymicrobial infections [63, 65]. An intrinsic resistance of $C$. albicans biofilms against most antifungal agents like fluconazole and amphotericin was reported [66-72]. The detailed mechanism of antifungal resistance of fungal biofilms remain unclear. It is known that $C$. albicans biofilm cells display reduced susceptibility to polyenes and azoles as compared to planktonic cells [8]. Improved efficacy of amphotericin B in combination with DNase I, which degrades eDNA in C. albicans biofilm matrixes, was observed [8]. Some results have shown that caspofungin is highly active against isolates demonstrating high levels of fluconazole resistance [73-75]. Rajendran et al. presented that Aspergillus fumigatus releases eDNA during autolysis in a phase-dependent manner. This is in agreement with previous studies conducted on Candida species, showing that the level of eDNA strictly correlates with the maturity of biofilm [58]. They also showed that DNase I treatment destabilised biofilm integrity in A. fumigatus [61]. Moreover, the authors demonstrated that the combination of DNase I with amphotericin B and caspofungin significantly improved antifungal activity.

\section{Conflict of interest}

The authors declare no conflict of interest.

\section{References}

1. Das T, Sehar S, Manefield M. The roles of extracellular DNA in the structural integrity of extracellular polymeric substance and bacterial biofilm development. Environ Microbiol Rep 2013; 5: 778-86.

2. Marsh PD, Moter A, Devine DA. Dental plaque biofilms: communities, conflict and control. Periodontology 2000 2011; 55: 16-35.

3. Wei Q, Ma LZ. Biofilm matrix and its regulation in Pseudomonas aeruginosa. Int J Mol Sci 2013; 14: 20983-1005.

4. Montanaro L, Poggi A, Visai L, et al. Extracellular DNA in biofilms. Int J Artif Organs 2011; 34: 824-31.

5. Pietrocola G, Arciola CR, Rindi S, et al. Toll-like receptors (TLRs) in innate immune defense against Staphylococcus aureus. Int J Artif Organs 2011; 34: 799-810.

6. Chambless JD, Hunt SM, Stewart PS. A three-dimensional computer model of four hypothetical mechanisms protecting biofilms from antimicrobials. Appl Environ Microbiol 2006; 72: 2005-13.

7. Baker-Austin C, Wright MS, Stepanauskas R, et al. Co-selection of antibiotic and metal resistance. Trends Microbiol 2006; 14: 176-82.

8. Martins M, Henriques M, Lopez-Ribot JL, et al. Addition of DNase improves the in vitro activity of antifungal drugs against Candida albicans biofilms. Mycoses 2012; 55: 80-5.

9. Hawser SP, Baillie GS, Douglas LJ. Production of extracellular matrix by Candida albicans biofilms. J Med Microbiol 1998; 47: 253-6. 
10. Finkel SE, Kolter R. DNA as a nutrient: novel role for bacterial competence gene homologs. J Bacteriol 2001; 183: 6288-93.

11. Molin S, Tolker-Nielsen T. Gene transfer occurs with enhanced efficiency in biofilms and induces enhanced stabilisation of the biofilm structure. Curr Opin Biotechnol 2003; 14: 255-61.

12. Mulcahy H, Charron-Mazenod L, Lewenza S. Extracellular DNA chelates cations and induces antibiotic resistance in Pseudomonas aeruginosa biofilms. PLoS Pathog 2008; 4: e1000213.

13. Tetz GV, Artemenko NK, Tetz VV. Effect of DNase and antibiotics on biofilm characteristics. Antimicrob Agents Chemother 2009; 53: 1204-9.

14. Zafra O, Lamprecht-Grandío M, de Figueras CG, et al Extracellular DNA release by undomesticated Bacillus subtilis is regulated by early competence. PLoS One 2012; 7: e48716.

15. Manzenreiter R, Kienberger F, Marcos V, et al. Ultrastructural characterization of cystic fibrosis sputum using atomic force and scanning electron microscopy. J Cyst Fibros 2012; 11: 84-92.

16. Vogelmeier C, Döring G. Neutrophil proteinases and rhDNase therapy in cystic fibrosis. Eur Respir J 1996; 9: 2193-5.

17. Cantin AM. DNase I acutely increases cystic fibrosis sputum elastase activity and its potential to induce lung hemorrhage in mice. Am J Respir Crit Care Med 1998; 157: 464-9.

18. Papayannopoulos V, Staab D, Zychlinsky A. Neutrophil elastase enhances sputum solubilization in cystic fibrosis patients receiving DNase therapy. PLoS One 2011; 6: e28526.

19. Arciola CR, Campoccia D, Ehrlich GD, et al. Biofilm-based implant infections in orthopaedics. Adv Exp Med Biol 2015; 830: 29-46

20. Whitchurch CB, Tolker-Nielsen T, Ragas PC, et al. Extracellular DNA required for bacterial biofilm formation. Science 2002; 295: 1487

21. Hall-Stoodley L, Nistico L, Sambanthamoorthy K, et al. Characterization of biofilm matrix, degradation by $\mathrm{DNa}$ se treatment and evidence of capsule downregulation in Streptococcus pneumoniae clinical isolates. BMC Microbiol 2008; 8: 173.

22. Parks QM, Young RL, Poch KR, et al. Neutrophil enhancement of Pseudomonas aeruginosa biofilm development: human F-actin and DNA as targets for therapy. J Med Microbiol 2009; 58: 492-502.

23. Lorenz MG, Wackernagel W. Bacterial gene transfer by natural genetic transformation in the environment. Microbiol Rev 1994; 58: 563-602.

24. Itzek A, Zheng L, Chen Z, et al. Hydrogen peroxide-dependent DNA release and transfer of antibiotic resistance genes in Streptococcus gordonii. J Bacteriol 2011; 193: 6912-22.

25. Fuxman Bass JI, Russo DM, Gabelloni ML, et al. Extracellular DNA: a major proinflammatory component of Pseudomonas aeruginosa biofilms. J Immunol 2010; 184: 6386-95.

26. Bauer S, Kirschning CJ, Häcker H, et al. Human TLR9 confers responsiveness to bacterial DNA via species-specific CpG motif recognition. Proc Natl Acad Sci U S A 2001; 98: 9237-42.
27. Hemmi H, Takeuchi O, Kawai T, et al. A Toll-like receptor recognizes bacterial DNA. Nature 2000; 408: 740-5.

28. Allesen-Holm M, Barken KB, Yang L, et al. A characterization of DNA release in Pseudomonas aeruginosa cultures and biofilms. Mol Microbiol 2006; 59: 1114-28.

29. Nemoto K, Hirota K, Murakami K, et al. Effect of Varidase (streptodornase) on biofilm formed by Pseudomonas aeruginosa. Chemotherapy 2003; 49: 121-5.

30. Passador L, Cook JM, Gambello MJ, et al. Expression of Pseudomonas aeruginosa virulence genes requires cell-tocell communication. Science 1993; 260: 1127-30.

31. Latifi A, Foglino M, Tanaka K, et al. A hierarchical quorum-sensing cascade in Pseudomonas aeruginosa links the transcriptional activators LasR and RhIR (VsmR) to expression of the stationary-phase sigma factor RpoS. Mol Microbiol 1996; 21: 1137-46.

32. Davies DG, Parsek MR, Pearson JP, et al. The involvement of cell-to-cell signals in the development of a bacterial biofilm. Science 1998; 280: 295-8.

33. Pearson JP, Gray KM, Passador L, et al. Structure of the autoinducer required for expression of Pseudomonas aeruginosa virulence genes. Proc Natl Acad Sci U S A 1994; 91: 197-201.

34. Pearson JP, Pesci EC, Iglewski BH. Roles of Pseudomonas aeruginosa las and rhl quorum-sensing systems in control of elastase and rhamnolipid biosynthesis genes. J Bacteriol 1997; 179: 5756-67.

35. Pesci EC, Iglewski BH. The chain of command in Pseudomonas quorum sensing. Trends Microbiol 1997; 5: 132-5.

36. Pesci EC, Milbank JB, Pearson JP, et al. Quinolone signaling in the cell-to-cell communication system of Pseudomonas aeruginosa. Proc Natl Acad Sci U S A 1999; 96: 11229-34.

37. Moscoso M, Garcia E, Lopez R. Biofilm formation by Streptococcus pneumoniae: role of choline, extracellular DNA, and capsular polysaccharide in microbial accretion. J Bacteriol 2006; 188: 7785-95.

38. Izano EA, Amarante MA, Kher WB, et al. Differential roles of poly-N-acetylglucosamine surface polysaccharide and extracellular DNA in Staphylococcus aureus and Staphylococcus epidermidis biofilms. Appl Environ Microbiol 2008; 74: 470-6.

39. Cole SJ, Records AR, Orr MW, et al. Catheter-associated urinary tract infection by Pseudomonas aeruginosa is mediated by exopolysaccharide-independent biofilms. Infect Immun 2014; 82: 2048-58.

40. Götz F. Staphylococcus and biofilms. Mol Microbiol 2002; 43: $1367-78$

41. Rice KC, Mann EE, Endres JL, et al. The cidA murein hydrolase regulator contributes to DNA release and biofilm development in Staphylococcus aureus. Proc Natl Acad Sci U S A 2007; 104: 8113-8.

42. Petersen FC, Pecharki D, Scheie AA. Biofilm mode of growth of Streptococcus intermedius favored by a competence-stimulating signaling peptide. J Bacteriol 2004; 186: 6327-31.

43. Houston P, Rowe SE, Pozzi C, et al. Essential role for the major autolysin in the fibronectin-binding protein-mediated Staphylococcus aureus biofilm phenotype. Infect Immun 2011; 79: 1153-65.

44. Kaito C, Hirano T, Omae Y, et al. Digestion of extracellular DNA is required for giant colony formation of Staphylococcus aureus. Microb Pathog 2011; 51: 142-8. 
45. Kaplan JB, Izano EA, Gopal P, et al. Low levels of betalactam antibiotics induce extracellular DNA release and biofilm formation in Staphylococcus aureus. mBio 2012; 3: e00198-12.

46. Kiedrowski MR, Kavanaugh JS, Malone CL, et al. Nuclease modulates biofilm formation in community-associated methicillin-resistant Staphylococcus aureus. PLoS One 2011; 6: e26714.

47. Qin Z, Ou Y, Yang L, et al. Role of autolysin-mediated DNA release in biofilm formation of Staphylococcus epidermidis. Microbiology 2007; 153: 2083-92.

48. Heilmann C, Thumm G, Chhatwal GS, et al. Identification and characterization of a novel autolysin (Aae) with adhesive properties from Staphylococcus epidermidis. Microbiology 2003; 149: 2769-78.

49. Vuong C, Gerke C, Somerville GA, et al. Quorum-sensing control of biofilm factors in Staphylococcus epidermidis. J Infect Dis 2003; 188: 706-18.

50. Carrolo M, Frias MJ, Pinto FR, et al. Prophage spontaneous activation promotes DNA release enhancing biofilm formation in Streptococcus pneumoniae. PLoS One 2010; 5: e15678.

51. Tomasz A, Moreillon P, Pozzi G. Insertional inactivation of the major autolysin gene of Streptococcus pneumoniae. J Bacteriol 1988; 170: 5931-4.

52. Steinmoen H, Knutsen E, Havarstein LS. Induction of natural competence in Streptococcus pneumoniae triggers lysis and DNA release from a subfraction of the cell population. Proc Natl Acad Sci U S A 2002; 99: 7681-6.

53. d'Enfert C. Hidden killers: persistence of opportunistic fungal pathogens in the human host. Curr Opin Microbiol 2009; 12: 358-64.

54. Bachmann SP, VandeWalle K, Ramage G, et al. In vitro activity of caspofungin against Candida albicans biofilms. Antimicrob Agents Chemother 2002; 46: 3591-6.

55. Crump JA, Collignon PJ. Intravascular catheter-associated infections. Eur J Clin Microbiol 2000; 19: 1-8.

56. Cannon RD, Chaffin WL. Oral colonization by Candida albicans. Crit Rev Oral Biol Med 1999; 10: 359-83.

57. Iraqui I, Garcia-Sanchez S, Aubert S, et al. The Yak1p kinase controls expression of adhesins and biofilm formation in Candida glabrata in a Sir4p-dependent pathway. Mol Microbiol 2005; 55: 1259-71.

58. Martins M, Uppuluri P, Thomas DP, et al. Presence of extracellular DNA in the Candida albicans biofilm matrix and its contribution to biofilms. Mycopathologia 2010; 169: 323-31.

59. Al-Fattani MA, Douglas LJ. Biofilm matrix of Candida albicans and Candida tropicalis: chemical composition and role in drug resistance. J Med Microbiol 2006; 55: 999-1008.

60. Paramonova E, Krom BP, van der Mei HC, et al. Hyphal content determines the compression strength of Candida albicans biofilms. Microbiology 2009; 155: 1997-2003.

61. Rajendran R, Williams C, Lappin DF, et al. Extracellular DNA release acts as an antifungal resistance mechanism in mature Aspergillus fumigatus biofilms. Eukaryot Cell 2013; 12: 420-9.

62. Rajendran R, Sherry L, Lappin DF, et al. Extracellular DNA release confers heterogeneity in Candida albicans biofilm formation. BMC Microbiol 2014; 14: 303.

63. Sapaar B, Nur A, Hirota K, et al. Effects of extracellular DNA from Candida albicans and pneumonia-related pathogens on Candida biofilm formation and hyphal transformation. J Appl Microbiol 2014; 116: 1531-42.
64. Felk A, Kretschmar M, Albrecht A, et al. Candida albicans hyphal formation and the expression of the Efg1-regulated proteinases Sap4 to Sap6 are required for the invasion of parenchymal organs. Infect Immun 2002; 70: 3689-700.

65. Pammi M, Liang R, Hicks J, et al. Biofilm extracellular DNA enhances mixed species biofilms of Staphylococcus epidermidis and Candida albicans. BMC Microbiol 2013; 13: 257.

66. Chandra J, Mukherjee PK, Leidich SD, et al. Antifungal resistance of candidal biofilms formed on denture acrylic in vitro. J Dent Res 2001; 80: 903-8.

67. Baillie GS, Douglas LJ. Candida biofilms and their susceptibility to antifungal agents. Method Enzymol 1999; 310; 644-56.

68. Hawser SP, Douglas LJ. Resistance of Candida albicans biofilms to antifungal agents in vitro. Antimicrob Agents Chemother 1995; 39: 2128-31.

69. Kuhn DM, George T, Chandra J, et al. Antifungal susceptibility of Candida biofilms: unique efficacy of amphotericin $\mathrm{B}$ lipid formulations and echinocandins. Antimicrob Agents Chemother 2002; 46: 1773-80.

70. Ramage G, Bachmann S, Patterson TF, et al. Investigation of multidrug efflux pumps in relation to fluconazole resistance in Candida albicans biofilms. J Antimicrob Chemother 2002; 49: 973-80.

71. Ramage G, Vande Walle K, Wickes BL, et al. Standardized method for in vitro antifungal susceptibility testing of Candida albicans biofilms. Antimicrob Agents Chemother 2001; 45: 2475-9.

72. Ramage G, Vandewalle K, Wickes BL, et al. Characteristics of biofilm formation by Candida albicans. Revista Iberoamericana de Micologia 2001; 18: 163-70.

73. Bachmann SP, Patterson TF, Lopez-Ribot JL. In vitro activity of caspofungin (MK-0991) against Candida albicans clinical isolates displaying different mechanisms of azole resistance. J Clin Microbiol 2002; 40: 2228-30.

74. Barchiesi F, Schimizzi AM, Fothergill AW, et al. In vitro activity of the new echinocandin antifungal, MK-0991, against common and uncommon clinical isolates of Candida species. Eur J Clin Microbiol Infect Dis 1999; 18: 302-4.

75. Vazquez JA, Lynch M, Boikov D, et al. In vitro activity of a new pneumocandin antifungal, L-743,872, against azole-susceptible and -resistant Candida species. Antimicrob Agents Chemother 1997; 41: 1612-4.

\section{Address for correspondence:}

\section{Prof. Robert Bucki PhD}

Department of Microbiological and Nanobiomedical Engineering

Medical University of Białystok

ul. Mickiewicza 2 C, 15-222 Bialystok, Poland

Phone: +48 857485483

E-mail: mikro.nano@umb.edu.pl 